\title{
EXPLORING SUPPLY CHAIN RISKS AMONG MALAYSIAN AUTOMOTIVE SMES
}

\author{
Norlaile Salleh Hudin ${ }^{1 *}$, Abu Bakar Abdul Hamid², Thoo Ai Chin ${ }^{3}$, Nurul Fadly \\ Habidin ${ }^{4}$ \\ ${ }^{1}$ Dr., Universiti Pendidikan Sultan Idris, Malaysia, norlaile@fpe.upsi.edu.my \\ ${ }^{2}$ Prof. Dr., Putra Business School, University Putra Malaysia, Malaysia, \\ bakarhamid3030@yahoo.com \\ ${ }^{3}$ Dr., Universiti Teknologi Malaysia, Malaysia, acthoo@utm.my \\ ${ }^{4}$ Dr., Universiti Pendidikan Sultan Idris, Malaysia, fadly@fpe.upsi.edu.my
}

${ }^{*}$ Corresponding author

\begin{abstract}
There is scant evidence pertaining to risks faced by Malaysian automotive SMEs, although many researches have been conducted in other countries. For that reason, this paper aims to explore supply chain risks experienced by Malaysian automotive companies. By using a case study method involving three Malaysian automotive SMEs, the data analysis reveals that Malaysian automotive SMEs are mostly affected by risks external to firm but internal to supply chain, particularly the risk of late delivery and part shortages. With respect to risk internal to firm, all three case companies admitted that human-related risk is putting pressure on them. The risks of force majeure events and government regulation emerge as the most common risks external to Malaysian automotive SME's supply chains. Although the results of this study are limited due to the small number of case companies investigated, they suggested automotive SMEs to implement multisourcing or develop closer relationship with sister companies and supply chain members to manage supply chain risks.
\end{abstract}

Keywords: Supply chain management, Supply risks, Automotive, SMEs

\section{INTRODUCTION}

According to Professor Martin Christopher, who is an expert of supply chain management (SCM), SCM encompasses both the internal management of the logistics processes that support the flow of product and related information as well as the upstream and downstream linkages with suppliers and customers (Camerinelli, 2009). Batten (2008) emphasized that one of the main benefits of practicing SCM is to decrease the risks related to purchasing activities. 
In general, SCM is no longer an alien concept especially among manufacturing companies. Surprisingly, however, supply chain risk has shown an increasing trend in recent years. In 2010, a McKinsey Global survey indicates that 71 percent of the executives in America reported that their companies were facing more risk from supply chain disruption than previously and 72 percent expected those risks to continue to increase in the next five years (McKinsey Global Survey Results, 2010). In another survey conducted in North America, 34 percent of the supply-side manufacturers had received queries from their buyers who experienced supply chain disruptions within the past quarter (MFGWatch Survey, 2010). A BBK Industry Week Survey further exposed that more than one-third of survey respondents in America said that over the past 12 months, they have had to halt or delay production due to supply chain capacity and/or resource issues (BBK, 2013). This survey also revealed that 84 percent of those impacted cited late deliveries and 55 percent said they paid premium shipping costs due to production stoppages (BBK, 2013).

Based on MFGWatch Survey conducted in early January 2010, 35 percent of the respondents, including automotive purchasing professionals, said that they had experienced a significant supply chain disruption (MFGWatch Survey, 2010) while one-third of the respondents also reported that they experienced a significant number and trend of supply chain disruptions (MFGWatch Survey, 2010). In further support, Punter (2013) reported 17 case studies of supply chain failures involving major companies such as Honda and Toyota.

Among the Asian region, South East Asia is right behind China, compared to India, Middle East and other Asian countries that cause the most costly outcomes from risk events in the automotive supply chain (Marchese, 2013). Despite that, not much is known about supply chain risks faced by Malaysian automotive small and medium enterprises (SMEs). The SMEs, compared to large automakers, seize the center stage when earlier research confirmed that having SMEs in supply chain increases overall supply chain risks (Henschel, 2008; Finch, 2004). The major concern here is that half of automotive suppliers in Malaysia are suppliers to PROTON, with 62.7 percent of them being SMEs (as cited in Ana Sakura Zainal Abidin et al., 2013). Therefore, the consequences of supply chain risks could easily spread across the whole sector. More recent evidence indicated that even PROTON, which used around 80 percent of Japan-sourced content (Seow, 2011) was disrupted because of earthquake and tsunami in Japan. Although PROTON's suppliers, which are mostly SMEs, did not operate in Japan, some of these suppliers sourced parts from Japan (Autoworld, 2011).

For the reasons discussed above, this research aims to explore risks that threatened automotive SMEs in Malaysia. This aim is particularly parallel with Chopra and Sodhi (2004), who strongly advised practitioners that they need to understand the types of risks as well as the events and conditions that manifest these risk events before they could alleviate those supply chain risks. This paper begins with a review of the existing literature and followed by the methodology, results, discussion and conclusion.

\section{LITERATURE REVIEW}

Certain risk classification or categorization is necessary for more systematic viewing and broader understanding about the source of the risks. Thus, earlier researchers, such as Wu et al. (2006), categorized risks into internal controllable, internal partially controllable, internal uncontrollable, external controllable, external partially controllable and external uncontrollable. Internal risks are those rooted from the company whereas external risks originate from outside of the company, such as the suppliers, customers or environment. In contrast, Norrman and Lindroth (2004) also proposed a risk typology which divided risks into three broad types, which are operational accidents, operational catastrophes and strategic uncertainty. Operational accidents describe the risks affecting day-to-day logistics or supply chain activities for example fires and resource failures with minor consequences. Operational catastrophes, on the other hand, cause more severe consequences than operational accidents but lower probability of occurrence such as economic crisis, natural disaster and political turbulence. The strategic uncertainties affect companies at the strategic level, for example supplier default or bankruptcy and technology change (Vanany et al., 2009).

Despite the supply chain risks categorizations provided by Wu et al. (2006) and Norrman and Lindroth (2004), this study utilized risk categorization proposed by Mason-Jones and Towill (1998). Mason-Jones and Towill (1998) divided risks into risks internal to the firm, risks external to the firm but internal to the supply chain and risks external to the supply chain. This is because a good risk classification should provide a clear distinction of each category of risk but the risk typology proposed by Wu et al. (2006) requires the users to judge the degree of risk controllability. The problem here is that the different conditions of companies could influence this degree of risk controllability. For example, compared to companies with weaker power over their suppliers, a company with greater power may have a higher degree of risk controllability for the same type of risk. Similarly, risk typology suggested by Norrman and Lindroth (2004) requires the users to determine the degree of risk consequence. Obviously, a fire may result in minor consequence and perceived 
as operational accidents but if that fire burnt down a facility that produces a unique and critical car component, should it still be considered as an operational accident? To avoid such confusion, this study applied Mason-Jones and Towill's (1998) risk categorization.

In narrower perspective, several scholars have attempted to identify specific risks in the automotive industry. Table 1 summarizes the risks commonly associated with automotive industry in the United States, Brazil, German and China. Based on these studies, poor quality of supplies is the most frequently occurring risk among automotive companies. Supplier bankruptcy, increased raw material prices, hurricane, tsunami, earthquake, union issues and shortages of supplies followed next. However, while observing Table 1, bear in mind that none of these studies investigated Malaysian automotive companies. The unique setting of Malaysian automotive industry, such as strong government protection and heavy reliance on foreign partners for continuous supply and technology transfer, may result in a different set of risks. In response to that matter, this paper conducted interviews to seek specific risks experienced by Malaysian automotive industry, and risk typology proposed by Mason-Jones and Towill (1998) is used to identify the origin of such risks. The next section discusses the research methodology in more detail.

Table 1. Risks in automotive industry

\begin{tabular}{|l|c|c|c|c|c|c|c|c|c|c|c|c|}
\hline \multicolumn{1}{|c|}{ Risk/Author } & $\mathbf{1}$ & $\mathbf{2}$ & $\mathbf{3}$ & $\mathbf{4}$ & $\mathbf{5}$ & $\mathbf{6}$ & $\mathbf{7}$ & $\mathbf{8}$ & $\mathbf{9}$ & $\mathbf{1 0}$ & $\mathbf{1 1}$ & $\mathbf{1 2}$ \\
\hline Hurricanes/storm & $/$ & & & & & & & & $/$ & $/$ & & \\
\hline Earthquake & & & & $/$ & $/$ & & & & $/$ & $/$ & & \\
\hline Tsunami & $/$ & & & $/$ & & & & & $/$ & $/$ & & \\
\hline Flood & $/$ & & & & & & & & & & & \\
\hline Fires & $/$ & & & & & & & & & & & \\
\hline War and terrorism & $/$ & & & & & & & & & & \\
\hline Political issues & & $/$ & & & & & & & $/$ & $/$ & & \\
\hline Debt and credit rating & & $/$ & & & & & & & $/$ & & & \\
\hline Liquidity and cash & & & & & & & & & & $/$ & & \\
\hline Currency exchange & & & & & & & & & & $/$ & & \\
\hline Interest/inflation rate fluctuation & $/$ & & & & & $/$ & $/$ & & & $/$ & & $/$ \\
\hline Increased raw material prices & & & & & & & $/$ & & & & & \\
\hline Increased setup cost & & & & & & & $/$ & & & & & \\
\hline Increased labor cost & & & & & & & $/$ & & & & & \\
\hline Increased transportation cost & $/$ & $/$ & & & & & & & $/$ & $/$ & & \\
\hline Union regulation/issues & & $/$ & & & & & & & & & & \\
\hline Operator error/accident damage & & $/$ & & & & & & & & & & \\
\hline Dealer relation & $/$ & & & & & $/$ & $/$ & & & & $/$ & $/$ \\
\hline Customer demand changes/forecast & $/$ & $/$ & $/$ & & & & & & & & & \\
\hline Property damage & & $/$ & $/$ & & & & & & & & & \\
\hline Theft & & & $/$ & & $/$ & $/$ & $/$ & & & & & \\
\hline Supply shortages & & & $/$ & & & $/$ & $/$ & $/$ & $/$ & & $/$ & $/$ \\
\hline Poor quality of supplies & & $/$ & & & $/$ & & & & $/$ & $/$ & $/$ \\
\hline Supplier bankruptcy/failure/financial & $/$ & & & & & & $/$ & & & & & \\
\hline Extended total cycle time (e.g. design \\
and production) & & & & & & & $/$ & & & & & \\
\hline Poor delivery time & & & & & & & & & & & & \\
\hline Delivery responsiveness & & & & & & & & & & \\
\hline Malfunction of IT system & & & & & & & & & & \\
\hline Immature regulation and policy & & & & & & & & & & \\
\hline
\end{tabular}

Sources: (1) Blackhurst et al. (2008); (2) Blos et al. (2009); (3) Trkman \& McCormack (2009); (4) Zolkos (2011); (5) Snyder (2011); (6) Thun \& Hoenig (2011); (7) Yong Lin (2011) (8) Wagner \& Neshat (2012); (9) Lockamy III \& McCormack (2012); (10) Scannell et al. (2013); (11) Jiantong et al. (2016); (12) Mohamed \& Youssef (2017) 


\section{METHODOLOGY}

This paper applied phenomenological case study approach among Malaysian automotive SMEs because to our knowledge, past studies paid considerable attention in studying automotive risks in Germany, China and Morocco (Tan et al., 2016; Jiantong et al., 2016; Mohamed \& Youssef, 2017). Therefore, three automotive SMEs were selected through purposeful sampling in order to find the informants with in-depth knowledge of an issue (Cohen et al., 2007) so that rich and detailed account of the phenomenon could be obtained. Creswell (2007) explained that purposeful sampling enables researchers to gain different perspectives of a situation and study typical or unique cases. To narrow down the scope of the study, PROTON's vendors were selected as the sampling frame for this study because PROTON is the largest automaker in Malaysia besides Perodua ("Malaysia: Business and Opportunities Investment Yearbook", 2008). Moreover, PROTON uses more than 90 percent of local content ("Produk Komponen Boleh Berdaya Saing", 2014) compared to other car makers in Malaysia. As a result, many parts manufacturers belong to PROTON ("Malaysia: Business and Opportunities Investment Yearbook", 2008). Particularly, more than half of PROTON suppliers are SMEs. To further represent the Malaysian automotive industry, a subsidiary of a renowned Japanese automaker was selected as a sample.

By using vendor assessment reports and feasibility studies, the case companies were selected based on PROTON's recommendation. Three cases were selected, which is in line with Creswell's (2007) suggestion that not more than four or five cases should be explored, in which for each case, three to five informants are recommended for interview. Semi-structured interview was employed because it enables the researcher to probe unexpected responses and build rapport with the informants to enhance the quality of responses (Lethbridge et al., 2005). To overcome the drawbacks of this method, which include response bias, inaccuracy of the data due to researchers' poor recall and reflexivity problem, as well as to triangulate the data, this study used documents analysis to ensure the consistencies of the information gathered from the interviews. The interviews were also tape-recorded to avoid any details being forgotten. Altogether, ten informants were interviewed as the data reached saturation. The number of informants satisfies Giorgi's (2009) suggestion, which is to have at least three informants for phenomenological study. Moreover, Klenke (2008) supported this recommendation as she proposed using between two to 25 informants. Finally, data were analyzed by using thematic analysis to capture latent and conceptual meaning of the responses. The interviews were first transcribed and then coded. The codes were then categorized to develop themes, which were then interpreted.

\section{FINDINGS}

\subsection{Case 1}

Based on the thematic analysis, the first case, which is the manufacturer of automotive gasket, was found to be involved primarily with risks external to supply chain and risks external to the firm but internal to the supply chain. However, risk internal to the firm was rarely mentioned. In conjunction with risk internal to firm, only one informant strongly emphasized on human-related risk whereas for risk external to the firm but internal to the supply chain, the informants agreed that their company is frequently threatened by changes of customer demand. Some customers did not provide demand forecast earlier while some customers tricked them by giving high demand forecast to gain quantity discount when in reality, these customers purchased lower volume. In even worse condition, instable relationship with customers caused the gasket manufacturer to absorb the cost of excess stocks that resulted from changing customer demands. Moreover, the gasket manufacturer also faced raw material shortage and late deliveries since most supply of parts and components were imported from foreign countries such as Japan and US and thus, required longer lead time. The gasket manufacturer further explained that the quality of cars manufactured by PROTON, their main customer, also concerned them because they perceived that they increase their supply chain risks when PROTON had difficulties in selling their cars.

Regarding the third type of risk, two out of four informants emphasized risk related to government regulation and only one informant spoke about force majeure event. According to one of the informants, the local automotive industry is currently in survival mode. By enforcing Common Effective Preferential Tariff (CEPT) and ASEAN Free Trade Area (AFTA), the gasket manufacturer expected that their main customer, PROTON, will be jeopardized as they will be involved in even tougher competition with other international cars assemblers in the South East Asian region. Regarding the force majeure event, high dependency on Japan for parts and components caused supply disruption to the gasket manufacturer when their $2^{\text {nd }}$-tier suppliers were ruined by the natural disasters. 


\subsection{Case 2}

Similar to the first case, the manufacturer of air-conditioner units demonstrated that they were most vulnerable towards the second category of risk, risk external to firm but internal to supply chain. Pertaining to risk internal to the firm, only one informant explained how inaccuracy of stock level had previously affected the production. When the volume of raw material was recorded higher than the actual physical count, there were shortage of raw material, which affected the production plan. He further elaborated that this problem mostly occurred because the employees neglected the standard operation procedures (SOP) for inventory recording.

While this problem is still manageable, this company had more to deal with risks external to firm but internal to supply chain, such as quality, flow of information, increased raw material price and the price of finished product. Three out of four informants reported the poor quality of raw materials imported from China, which accounted for the majority of the raw materials for this company. Clearly, the air-conditioner manufacturer had difficulties in controlling the quality standard of Chinese suppliers because they were located far away. Consequently, it obstructed them from conducting frequent visits to the suppliers' sites. In addition, their Chinese suppliers also limited the flow of information to the air-conditioner manufacturer by not submitting and even counterfeiting routine reports. The global sourcing strategy further exposed this company to currency exchange risk, which so far caused them to experience increased raw material prices. Without this cost advantage, the air-conditioner manufacturer had to increase the selling price of their finished products. As automotive component companies are deeply involved in fierce rivalry, the increase of finished product price does not help this company to gain competitive advantage. At a lesser extent, only one informant mentioned supplier's bankruptcy. However, this informant further reported that the suppliers who went out of business were all local suppliers.

In conjunction with risk external to supply chain, two out of four informants claimed that the flow of raw material supplies from Japan and Thailand was disrupted due to tsunami and flood. Moreover, they had to postpone the delivery of finished products to customers in Thailand as well since the customer's facilities were damaged by flood.

\subsection{Case 3}

The company for the third case produced plastic automotive parts, such as dashboards and car bumpers. Human-related risk emerged as the only risk mentioned by the informants of this company, which falls under the category of risk internal to firm. However, one of the informants stressed that human-related risk had once caused a major impact to this company. He explained that this company depended heavily on formal and standardized procedures to control the occurrence of risks but such strict procedures required men as the major instruments. Given this condition, the failure rooted from human flaws often delayed the flow of supplies to this company.

Furthermore, the informants also declared that they are frequently threatened by risks external to firm but internal to the supply chain, especially part shortages, delivery delay and downtime. They explained that part shortages could happen due to mixed product variants and delay in delivery. Since most supplies are imported overseas, the delivery of supplies is subject to port congestion, bad weather and the performance of carrier. The informant explained that they had major disruption in March 2014 when the ocean carrier that transported their supplies from Philippines changed route to Taiwan without any notice. On the downside, the occurrence of part shortages and disrupted delivery could result in production downtime at customers' facilities. In that case, this company could be charged for RM720, RM630 and RM1000 per minute of downtime by customers in Malaysia, Thailand and Japan respectively.

Although risks external to supply chain particularly government regulation and force majeure events do not occur so often, they could not be controlled much by the plastic automotive components manufacturer. With respect to government regulation, this company was obligated to excise duty, which they believed was difficult to control. Although they implemented localization program to reduce the excise duty, they still could not bring down the final selling price lower than national cars. In addition, since most electronics parts were imported from Japan, the occurrence of tsunami had interrupted the flow of supplies. Similarly, they also stopped their production because their customers in Thailand were hit by heavy flood. Overall, Table 2 summarizes the findings of this research. 
Table 2. Summary of automotive risks

\begin{tabular}{|c|l|l|l|}
\hline $\begin{array}{c}\text { Case/ Types } \\
\text { of risk }\end{array}$ & $\begin{array}{c}\text { Risks internal to } \\
\text { the firm }\end{array}$ & $\begin{array}{l}\text { Risks external to the firm but } \\
\text { internal to the supply chain }\end{array}$ & \multicolumn{1}{c|}{$\begin{array}{c}\text { Risks external to } \\
\text { supply chain }\end{array}$} \\
\hline Case 1 & Human-related risk & $\begin{array}{l}\text { Customer demand changes } \\
\text { Raw material shortage } \\
\text { Late deliveries } \\
\text { Quality of cars manufactured by } \\
\text { customers }\end{array}$ & $\begin{array}{l}\text { Government regulation } \\
\text { Force majeure events }\end{array}$ \\
\hline Case 2 & Human-related risk & $\begin{array}{l}\text { Quality of raw material } \\
\text { Global sourcing } \\
\text { Increased raw material price } \\
\text { Increased finished product price } \\
\text { Suppliers' bankruptcy }\end{array}$ & Force majeure events \\
\hline Case 3 & Human-related risk & $\begin{array}{l}\text { Raw material shortages } \\
\text { Late delivery } \\
\text { Production downtime }\end{array}$ & $\begin{array}{l}\text { Government regulation } \\
\text { Force majeure events }\end{array}$ \\
\hline
\end{tabular}

\section{DISCUSSION}

This study found that most of the risks affecting all three case companies were risks external to the firm but internal to the supply chain. In conjunction with risk internal to the firm, all three case companies agreed upon human-related risk. In detail, the case companies reported that the staff occasionally ignored SOP intentionally or unintentionally. However, to the best of our knowledge, only one past research focused on this aspect, i.e. Blos et al. (2009), who mentioned operator error. Clearly, this risk has yet to be solved effectively and more studies should be dedicated to investigate human-related risks in the automotive industry.

Regarding risk external to the firm but internal to the supply chain, previous researches revealed that quality of supplies received a greater deal of attention (Trkman \& McCormack, 2009; Thun \& Hoenig, 2011; Yong Lin \& Li Zhou, 2011; Wagner \& Neshat, 2012; Lockamy III \& McCormack, 2012). Nevertheless, this study proves that only one of the case companies, the air-conditioner manufacturer, experienced this problem. Deeper investigation exposed that the poor quality automotive parts and components were sourced from China. On the other hand, the gasket and plastic components manufacturers purchased raw materials mostly from Japan and other foreign countries. After the world war, Japan went through an era of "Japanese quality revolution" (O'Conner \& Kleyner, 2012) and since then, they never looked back and kept on producing quality automotive parts and components. In stark contrast, China is notorious for producing poor quality parts. For example, Aston Martin was forced to recall their sport cars when counterfeit plastic materials supplied from China was found in the accelarator pedal (Pomfret et al., 2014). To lend further support, Navarro (2008) admitted that in many cases, China automotive parts have poor quality that often lead to dangerous failure. Based on this study, apparently, the dominant influence of Japan in case 1 and 3 caused most of the supplies to be imported from Japan. Due to this situation, quality risk is under control at the gasket and automotive plastic manufacturers compared to the air-conditioner manufacturer. Nevertheless, the gasket manufacturer also expressed their concern about the overall quality of cars produced by PROTON, their main customer.

Although case 1 and 3 did not reveal any risk pertaining to the quality of parts and components, the risk of late delivery and raw material shortage concerned them. Therefore, this finding supports previous researches, which verified that the automotive industry is burdened by supply shortages (Trkman \& McCormack, 2009; Snyder, 2011; Thun \& Hoenig, 2011; Yong Lin \& Li Zhou, 2011). When probing into this issue, this study found that importing automotive parts and components from Japan raised the risk of raw material shortage. First, the Japanese suppliers were shortening their lead time from three months to one and a half months, thus last minute orders were often rejected. As a consequence, the case companies used backup suppliers but sometimes, delivery time had to be compromised. Secondly, being located far away from Malaysia, the supplies were usually shipped through ocean carriers that required months to arrive. Considering the weak logistics system in Malaysia (Williams, 2014) and inefficient clearance procedures at Malaysian ports (Mohd Hafizzuddin Md Damiri, 2008), Malaysian automotive companies, which depend largely on foreign suppliers, are frequently facing late deliveries (Williams, 2014; Wan Hasrulnizzam Wan Mahmood et al., 2009).

With respect to risk external to the supply chain, the finding corroborates with earlier studies (Blackhurst et al., 2008; Zolkos, 2011; Snyder, 2011; Lockamy III \& McCormack, 2012; Scannell et al., 2013) when all three case companies experienced the risk of force majuere events especially earthquake and tsunami in Japan 
and major flood in Thailand. This consistency of result can be explained by a report which revealed that more than 50 percent of auto suppliers are located in just four countries, including Taiwan, China, USA and Japan, and many of these hotspots for high-tech and automotive suppliers are in areas known for susceptibility to natural disasters ("Global Supply Chain Risk Is Concentrated and Concealed in Sub-tier Suppliers", SDCExec, 2013). Ayutthaya province in Thailand, which was once hit by heavy flood, is also well-known as the home for many automotive factories. For that reason, any natural disaster occurring in these areas can cause ripple effects that affect the automotive industry at a global scale.

\section{CONCLUSION}

Increasing statistics of supply chain risks in automotive industry catches attention from researchers worldwide. From practitioners perspective, understanding the nature, events and conditions that materialize the risks can help them formulating better risk countermeasures (Chopra \& Sodhi, 2004). Nevertheless, research on supply chain risk in Malaysian automotive industry is particularly scarce despite the fact that Malaysia has been involved in this sector since 1983.

Therefore, this study explored supply chain risks experienced by three selected case companies. Earlier findings showed that poor quality of materials was the most frequent supply chain risk in automotive supply chain. Past studies further described that supplier bankruptcy, increased raw material prices, force majuere events, union issues and shortages of supplies are among the important risks inherent in automotive supply chain. Despite that, this study discovered that among the three selected companies, poor quality of raw materials was a concern only to air-conditioner manufacturer because they imported parts from Chinese suppliers, which had quality control problems. The other two case companies purchased most parts from Japan and other countries that implement a better quality management system. However, the companies that sourced parts from Japan encountered late delivery risk. Human-related risk, which has been commonly neglected in the current literature, surprisingly is a common risk among the case companies. Aligning with past studies, this paper found that force majuere events affected all case companies in this investigation.

Overall, this study clarifies that most supply chain risks experienced by the three case companies are rooted from risk external to the firm but internal to supply chain. Due to the nature of this type of risk, automotive SMEs and other members of the supply chain are suggested to develop more transparent relationship so that any signals of risk occurrence could be shared as soon as possible to limit greater consequence. For late delivery risks, companies can implement multi-sourcing or at a lesser extent, develop close and stronger relationship with sister companies in nearby countries. This is because many automotive SMEs are subsidiaries of international automotive parts manufacturer, which has several other subsidiaries located in different countries. Since supplier development is not easy nor inexpensive, working hand-in-hand with sister companies may be seen as a more practical approach to manage supply chain risks. With regards to humanrelated risks, this study indicates that employees' skills and trainings are still inadequate and more intensive training activities are necessary than just buddy system or on-the-job-trainings, which are commonly conducted in the Malaysian automotive industry. Finally, industrial areas in Malaysia have yet to be hit by force majuere events, thus localization program seems to be a suitable long-term strategy to ensure the continuity of business operations.

The outcome of this study is somehow limited by the small number of cases but looking at the brighter side, this research has shed some light into the critical types of risks experienced by Malaysian automotive SMEs. Obviously, more attention should be paid on reducing or eliminating these risks to push the Malaysian automotive industry forward. Nevertheless, future researches that employ survey method are strongly recommended to gain insight into supply chain risk at a larger scale.

\section{REFERENCE LIST}

Autoworld. (2011, March 22). Proton Comments on Japan Earthquake. Autoworld.com.

Batten, L. (2008). Supply Chain Management 100 Success Secrets - 100 Most Asked Questions. North Carolina: Lulu Enterprise, Inc.

BBK/IndustryWeek Study Reveals Concerning Results About Supply Chain Risk Visibility as Economy Recovers. (2013, September 21). Journal of Transportation, p. 58.

Blackhurst, J. V., Scheibe, K. P., \& Johnson, D. J. (2008). Supplier Risk Assessment and Monitoring for the Automotive Industry. International Journal of Physical Distribution \& Logistics Management, 38(2). 
Blos, M. F., Quaddus, M., Wee, H. M., \& Watanabe, K. (2009). Supply Chain Risk Management (SCRM): A Case Study on the Automotive and Electronic Industries in Brazil. Supply Chain Management: An International Journal, 14(4).

Camerinelli, E. (2009). Measuring the Value of the Supply Chain: Linking Financial Performance and Supply Chain Decisions. Surrey: Gower Publishing Limited.

Chopra, S., \& Sodhi, M. S. (2004). Managing Risk to Avoid Supply-Chain Breakdown. MIT Sloan Management Review, 46(1).

Finch, P. (2004). Supply Chain Risk Management. Supply Chain Management: An International Journal, $9(2)$.

Global Supply Chain Risk Is Concentrated and Concealed in Sub-tier Suppliers. (2013, August 19). SDCExec.com.

Henschel, T. (2008). Risk Management Practice of SMEs: Evaluating and Implementing Effective Risk Management Systems. Berlin: Erich Schmidt Verlag GmbH \& Co.

Jamaluddin bin Muhammad. (2011, October 17). Malaysian Auto Parts Plant Saves Some Equipment From Floods. Bernama.

Jiantong, Z., Zhuoqi, G., \& Xiaodong, C. (2016). Evaluation of automotive supply chain risks: An empirical research. 13th International Conference on Service Systems and Service Management (pp. 1-6). Kunming, China: Institute of Electrical and Electronics Engineers, Inc .

Lockamy III, A., \& McCormack, K. (2012). Modeling Supplier Risks Using Bayesian Networks. Industrial Management \& Data System, 112(2).

Malaysia: Business and Opportunities Investment Yearbook (6th ed.). (2008). Washington: International Business Publications, USA.

Marchese, K. (2013). The Ripple Effect: How Manufacturing and Retail Executives View the Growing Challenge of Supply Chain Risk. New York: Deloitte Development LLC.

McKinsey Global. (2010). The Challenges Ahead for Supply Chain: McKinsey Global Survey Results.

MFGWatch Survey: Manufacturers Continue To Experience High Levels of Supply Chain Risk, Do Not Add Jobs, Maintain Capacity As Expected. (2010, February 10). Defense \& Aerospace Week, p. 118.

Mohamed, E. A., \& Youssef, M. M. (2017). Analysis of risk factors and events linked to the supply chain: Case of automotive sector in Morocco. Journal of Logistics Management, 6(2), 41-51.

Mohd Hafizzuddin Md Damiri. (2008). Enhancing Port Efficiency in Malaysia through Technology Applications. Kuala Lumpur: Malaysian Logistics Council.

Navarro, P. (2008). The Coming China Wars: Where They Will Be Fought and How They Can Be Won. Upper Saddle, NJ.: Pearson Education.

Norrman, A. \& Lindroth, R. (2004). Categorization of supply chain risk management. In C. Brindley (Ed.)., Supply Chain Risk, Aldershot: Ashgate.

O'Conner, P., \& Kleyner, A. (2012). Practical Reliability Engineering (5th ed.). West Sussex, UK: John Wiley \& Sons.

Pomfret, J., Shirouzu, N., \& Frost, L. (2014, February 11). Aston Martin Recall Highlights Risk of China Parts Supply. Reuters.

Produk Komponen Boleh Berdaya Saing. (2014, Februari 17). Utusan Malaysia.

Scannell, T. V., Curkovic, S., Wagner, B. J., \& Vitek, M. J. (2013). Supply Chain Risk Management within the Context of COSO's Enterprise Risk Management Framework. Journal of Business Administration Research, 2(1).

Snyder, J. (2011, May 30). Survey Finds Suppliers Short on Capacity. Crain's Detroit Business, 27(22).

Tan, M., Aydem, A., \& Dağdeviren, M. (2016). Using the analytic hierarchy process (AHP) for supply chain risk management (SCRM): A case study in automotive sector . LM-SCM XIV International Logistics and Supply Chain Congress, (pp. 191-202). Izmir, Turkey.

Thun, J.-H., \& Hoenig, D. (2011). An Empirical Analysis of Supply Chain Risk Management in the German 
Automotive Industry. International Journal of Production Economics, 131(2011).

Trkman, P., \& McCormack, K. (2009). Supply Chain Risk in Turbulent Environments—A Conceptual Model for Managing Supply Chain Network Risk. International Journal of Production Economics, 119.

Wagner, S. M., \& Neshat, N. (2012). A Comparison of Supply Chain Vulnerability Indices for Different Categories of Firms. International Journal of Production Research, 1-15.

Wan Hasrulnizzam Wan Mahmood, Mohd Razali Muhamad, \& Nurulain Mat Tahar. (2009). Supply Chain Management: After Business Process Re-Engineering. International Journal of Social, Education, Economics and Management Engineering, 3(5).

Williams, M. (2014, January-March). Gaining Power Through Diversity. Automotive Logistics, p. 62.

Wu, T., Blackhurst, J., \& Chidambaram, V. (2006). A model for inbound supply risk analysis. Computers in Industry, 350-365.

Yong Lin, \& Li Zhou. (2011). The Impacts of Product Design Changes on Supply Chain Risk: A Case Study. International Journal of Physical Distribution and Logistics Management, 41(2).

Zolkos, R. (2011). Supply Risks Take Priority: Disaster in Japan Highlights Exposures Many Companies Face. Business Insurance, 45(31). 